announced, and the quantitative composition of Sorby's pearly constituent determined. This paper is admitted on all sides to be a classic.

In 1896 , in "The Influence of Impurities on Gold and Copper" (Arnold and Jefferson), the first micrographic investigation of gold alloys was described, and the discovery of brittle intercrystalline cements rendered void atomic volumes as an explanation of the results. 1897 produced "The Influence of Sudden Cooling on Nearly Pure Iron" (Arnold), and "The Permeability of Steel-melting Crucibles" (Arnold and Knowles), which showed a method for quantitatively measuring the volume of gas permeating the walls of crucibles $\frac{3}{4}$-inch thick during metallurgical operations. "The Micro-chemistry of Cementation" was read in 1898 , and the discovery of the cause of the decay of certain metals used in marine construction in connection with the disastrous explosion on the S.S. Prodano was given in a report to Lloyd's. "The Diffusion of Elements in Iron " (Arnold and McWilliam, i899) divided the elements of steel into fixed and migratory groups and confirmed Prof. Campbell's diffusion of sulphide phenomena. During this research two very important phases of carbide interpenetration at different temperatures were discovered, and also a hitherto unsuspected segregation point which has cleared up some of the occasional mysterious failures of the highest grade cutting edge steel.

"The Properties of Steel Castings, Part i." (Arnold, I9OI) dealt with pure iron and carbon castings, and showed their unsuitability for general commercial work. "The Micro-structure of Hardened Steel" (Arnold and McWilliam, I9O2), amongst other things, first showed the cementite in the so-called austenite martensite structure. "The Elimination of Silicon in the Acid Open Hearth" (McWilliam and Hatfield, I902) is an interesting study, under works conditions, of chemistry at high temperatures in the reaction of metal and slag on each other, in which a balance point in the composition of the slag was discovered, such that with more base $\mathrm{C}, \mathrm{Si}$, and $\mathrm{Mn}$ were eliminated from the metal, whilst with more acid $C$ could still be eliminated, but $\mathrm{Si}$ and $\mathrm{Mn}$ were reduced and returned to the bath. "The Influence of Sulphur and Manganese on Steel" (Arnold and Waterhouse) and " On the Dangerous Crystallisation of Steel " (Arnold) were produced in 1903 , and in the latter the author announced his now well-known method for recording results of steel under alternating stress, the stress being greater than the elastic limit instead of less, as is the case in other methods. "Acid Open Hearth Manipulation" (McWilliam and Hatfield, 1904) is another high temperature chemistry study on a 25 -ton furnace, with unusual bases, in which also it was shown that the nature of the ingot is not merely a function of its composition as ordinarily determined, but varies with the history of the charge in a special manner shown. "The Thermal Transformations of Carbon Steels" (Arnold and McWilliam, I904), too complex to describe in a sentence, shows the nature of the transition forms of the constituents of steels by quenching so as to trap several forms in one small section, where they can be studied somewhat after the manner of examining rock changes over a tract of country. Winder and Brunton did early work on open hearth chrome steel castings; Longmuir here worked out what had been borne in upon him by his works experience, resulting in his two researches on "The Influence of Casting Temperature on the Properties of Metals and Alloys "; Baker did his work on "The Influence of Silicon on Iron," and half the work resulting in Ibbotson and Brearley's well-known book on "The Analysis of Steel Works Materials" is of this laboratory. The above is not by any means a complete list, but is intended to indicate the principal and to give a good idea of the original work done, which has been acknowledged by practical as well as by professional men to have had great and important influence.

With regard to the students trained, every works of any importance in the district has its quota of them, and many are reflecting great credit on their school by the success with which they are holding responsible positions. There is no doubt that all firms of importance, having ready at hand well-trained men, formed a potent factor in the signal success with which Sheffield not only repelled the American invasion of high speed steel, but was able promptly and successfully to carry the war into the enemy's territory. The associateship in metallurgy has always been kept up to about the standard of an honour examination, no second classes being allowed, and the fight for the Mappin medal and ${ }_{5} l$. premium given to the head associate of the year is long and severe. This medal and premium was founded by Sir Frederick Mappin, Bart., who has consistently for more than twenty years used not only his wealth, but his great influence with others, and his foresight and dogged perseverance, in furthering the cause of this technical department. His recent purchase and practical presentation of the adjacent Caledonian Works has enabled the authorities to apply their fifteen years' experience during the erection of a new and magnificent teaching plant, which has been so recently described that it need not have further mention here. Finally, as to the attitude of manufacturers, few who followed with interest the doings of fifteen years ago would have prophesied that steel makers would send for associates at the end of each session, or that some even would ask for "your medallist of the year if possible," but such is the fact to-day.

All Sheffielders asked feel certain that but for the continued success of this and the technical department as a whole, Sheffield would never have successfully demanded a university, and that, indeed, the university inaugurated by the King on July 12, 1905, nay be taken as a monument to one of the influences of the technical department. Twice in its history has this progressive department had to sever its connection with constituted authority, and many are looking, somewhat anxiously it must be confessed, to its progress under the cumbrous machinery of university government, with its several forms of outside interference. Change and progress are not now decided upon by those immediately interested, for at least a majority of a governing body, composed of professors of all and sundry, must sanction all decisions, and in its effect on this hitherto uniformly progressive and successful department university government is undoubtedly on its trial, so far as its influence on the application of science to industry is concerned.

\section{EARTH-EATERS IN INDIA.}

UNDER the name of geophagy or earth-eating are comprehended a number of customs of very different origin and meaning. In practically every part of the world is found the habit of eating finely divided mineral substances in bulk, and not merely in small quantities as condiments; but the purpose differs no less widely than the condition of the eaters as regards age, sex, or health before and after acquiring the habit. We learn from Pliny that the Romans mixed corn with chalk from near Puteoli; Lemnian and Armenian earths, on the other hand, were famous for medicinal purposes-the use of the former has been continued to our own day; in South America clay supplies the place of food during floods; in Borneo and

No. I926, voL. 74] 
Indo-China it is a surrogate for confectionery, and in parts of India, America, and elsewhere its use is due to the perverted taste often found in dyspepsia and hysteria, or to the strange abnormalities associated with pregnancy.

In the paper here noticed ${ }^{1}$ the composition of the earth, marl, clay, or shale has been carefully analysed; the main constituents are silica (the percentage varying from 84 per cent. to 22 per cent.), lime (6I per cent. to a mere trace), alumina ( 26 per cent. to 2.5 per cent.), and ferric oxide ( 20 per cent. to a mere trace). But as a rule there is little definite information, other authors being content to speak of clay or earth without closer definition. We know, however, that steatite is favoured by the Indians of Hudson's Bay, and ferruginous clay by the Ottomacs, by the negroes of the Antilles, and by the Batanga of West Africa; earth rich in diatoms is used in North Europe, and the New Caledonians resort in time of famine to a mineral rich in lime, and ants' nests, with or without the larvæ, are eaten in Africa. The physiological basis of the habit varies probably in some degree with the different composition of the earths. On the Gold Coast white clay is used as a sweetmeat; in India the taste or odour is often the attractive feature; it may be noted in this connection that steatite (one of the minerals mentioned above) is not only eaten by wolves, reindeer, and other animals, but actually used as bait for attracting them. To the pleasant taste may be due the Roman use of chalk mentioned above; we have a parallel in the Bolivian Indian's use of a sauce of clay with his potatoes. In this category, too, we may range the German workman's "Steinbutter," and perhaps the salty earth used in Persia. In Senegal ochreous earth is mixed with rice, but it does not appear whether this is due to its pleasant taste or to a desire to increase the mass available for ingestion so as to produce a feeling of repletion.

In Rajputana the latter cause is undoubtedly the main factor; for only in times of famine are ashes, powdered steatite, clay or mud mingled with barkmeal. On the other hand, it is not so much actual famine in Persia as the desire to keep the digestive organs at work without suffering inconvenience from an over-supply of nourishment which is said to lead to the use of the two kinds of earth frequently sold in bazaars; one is described as a fine, white, "fatty" clay, the other as forming hard and irregular lumps. The material of ants' nests, like the Bergmeh (Kieselgur) of North Europe, is rich in organic matter, and may have real nutritive value; but on this point little positive information is available.

Especially in India the habit of earth-eating is indicative of a morbid condition, either anterior to the acquisition of the taste or after it has been adopted from imitation or some other cause. The same conditions seem to prevail widely in South America, where not only Indians and negroes, but whites, are slaves to the practice; it is even said that masks are put on children at night to restrain them from pulling mud or plaster from the walls and eating it.

The medicinal use of earths is a wide subject on which a large literature exists; our authors quote, among others, El-Baitar, who gives a list of the earths used in Spain in the thirteenth century; but the use of mineral substances in medicine hardly belongs to the same category as the other facts with which they deal; the same may be said of the ingestion of earths for magical purposes.

The effects on the eater seem to differ widely. In West Africa no bad effects follow, according to some

1 " Earth-eating and the Farth-eating Habit in India." Bv D. Honper and H. H. Mann. (Memoirs of the Asiatic Society of bengal, vol. I., No. ч2, pp. 249-270.)

No. 1026 . vOL. 747 authors; but when the negroes reached the West Indies they found that ill-health resulted from their indulgence in decomposed porphyroid lavas as substitutes for their African earths. In India and South America anæmia and early death seem to follow as a matter of course, but the anæmic diathesis often exists before the habit is acquired, and may be the actual cause of it.

The quantity of earth or clay consumed is often considerable. Half a pound daily is the allowance for the Ottomacs; six ounces is recorded from Bengal. They are sometimes eaten raw, sometimes roasted; one of the most curious features is that the earth or clay is sometimes made up into cups, figurines, and other forms; thus the Lemnos earth used in Spain in the sixteenth century was cup-shaped, so is the clay used to-day in Bengal; in Bolivia figures of saints are among the forms, and the Javanese eat figures of men and animals. In these cases a magical element may perhaps be present. But the commoner form is that of powder; the only edible earth of which the present writer can speak from personal experience was in this shape; it was alkaline and more like tooth-powder than anything else.

N. W. T.

\section{NOTES.}

DR. L. A. BAUER's resignation from the United States Coast and Geodetic Survey took effect on September 1 . As already announced in NATURE, he has accepted the permanent directorship of the department of terrestrial magnetism of the Carnegie Institution of Washington. All his correspondence should be addressed to "The Ontario," Washington, D.C.

Ar the annual meeting of the Hull Scientific and Field Naturalists' Club just held, Mr. T. Sheppard, who for thirteen years has been the honorary secretary, was elected president of the society.

Prof. A. H. ChURCh, F.R.S., will give six lectures on chemistry at the Royal Academy of Arts on Mondays and Thursdays, beginning on October I at $4 \mathrm{p} . \mathrm{m}$. The subjects of the lectures are:-Paper, canvas, panel, and other grounds; composition and classification of pigments; tests and trials of pigments; selected and restricted palettes; vehicles and varnishes; and methods of painting.

A Note from the Rev. Guy Halliday recording the discovery of Goodyera repens near Holt, in Norfolk, was referred to in Nature of September 6 (p. 472). Mr. W. A. Nicholson, honorary secretary of the Norfolk and Norwich Naturalists' Society, informs us that the plant was found at Holt so far back as $\mathrm{3} 89 \mathrm{I}$, and at Westwick in 1885 . It has since been noted in two other places in Norfolk.

A Reuter message from Palermo states that earthquake shocks were felt on September 19 at II.20 a.m. and I.38 p.m., principally at Trabia and Termini. A message from Lima reports that shocks were felt on September 18 at Huarmey, Alija, and Casma.

AN International Congress for Cancer Research was opened at Heidelberg on Tuesday by the Grand Duke and Grand Duchess of Baden in the presence of numerous representatives of medical, scientific, and municipal institutions of the world. At the same time, a new hospital and scientific laboratories for investigations into the cause and cure of cancer was opened. We learn from the Times correspondent at Heidelberg that the new buildings occupy nearly an acre, and are fitted with all the latest improvements, both for the treatment of operable cases and for 